\title{
English Language Needs Analysis of Qur'anic Sciences and Tradition Students in Iran
}

\author{
Hadi Salehi ${ }^{1}$, Ameneh Davari ${ }^{1} \&$ Melor Md Yunus ${ }^{2}$ \\ ${ }^{1}$ English Department, Faculty of Humanities, Najafabad Branch, Islamic Azad University, Najafabad, Isfahan, \\ Iran \\ ${ }^{2}$ Faculty of Education, Universiti Kebangsaan Malaysia, Bangi, Malaysia \\ Correspondence: Hadi Salehi, English Department, Faculty of Humanities, Najafabad Branch, Islamic Azad \\ University, Najafabad, Isfahan, Iran. E-mail: hadisalehi1358@yahoo.com
}

Received: November 21, 2014 Accepted: March 25, 2015 Online Published: May 28, 2015

doi:10.5539/elt.v8n6p50 URL: http://dx.doi.org/10.5539/elt.v8n6p50

\begin{abstract}
Needs analysis is fundamental to determine what students need to achieve through the medium of English accurately analysis. In this regard, the present study seeks to evaluate the ESP course book entitled "The ESP Course of Qur'anic Sciences and Tradition" taught at some universities in Iran. More specifically, the study aims to identify the students' perceptions of their needs and their attitudes towards the course book. To this end, a researcher-made questionnaire was used and accordingly an interview was run. Sample of this study consisted of 80 junior students majoring in Qur'anic Sciences and Tradition and 6 teachers teaching them. Results of the study revealed that the course book is appropriate for the students of the Qur'anic Sciences and Tradition course in general sense. However, the book did not get high evaluation in some issues. The findings of this study would enable the ESP instructors to pay more attention to the students' needs in designing the Qur'anic Sciences and Tradition textbook. The paper concludes with suggestions that may help improve the current English language course based on the students' attitudes and needs.
\end{abstract}

Keywords: ESP, textbook evaluation, needs analysis, Qur'anic sciences and tradition students, learners' attitudes

\section{Introduction}

Teaching of English for Specific Purposes (ESP) has been as a separate activity within English language teaching (ELT) and has been regarded as an approach which is widely used over the past three decades. There are numerous definitions for ESP but all of them emphasize how teaching of ESP develops appropriate procedures to learners whose main goal is not only learning language but also learning English for a specific purpose. These goals may be educational, professional, or personal. ESP is capable of preparing the learners to achieve the required goals.

Aiming at defining ESP, Richards and Rodgers (2001) clarified it as one of the subfields of Language for Specific Purposes (LSP). They believed that LSP is "a movement that seeks to serve the language needs of learners who need language in order to carry out specific roles (e.g., student, engineer, technician, nurse) and who thus need to acquire content and real-world skills through the medium of a second language rather than master the language for its own sake" (p. 207). Similarly, Hutchinson and Waters (1993, p. 19) as stated in Karimi (2006) defined ESP as an approach to language teaching in which all decisions concerning content and method are based on the learners' needs. They claim that the basic principle of ESP is to find learners need English for what, and then teach them the English that they need. Therefore, teaching ESP is a challenging and time consuming task.

Learner's need is one of the distinguishing characteristics which make ESP distinct from other approaches to language pedagogy (Robison, 1991, as cited in Jahangard, 2007). Salehi, Davari, and Md Yunus (2015) defined needs analysis as the process in which information is gathered and interpreted on what the learners need to do in the learning settings in order to learn the target language. In today's classrooms, textbooks are a key component in most language program. As Riazi (2003, p. 52) put it, "textbooks play a very crucial role in the realm of 
language teaching and learning and they are considered the next important factor in the second/foreign language classroom after the teacher" (Danaye Tous \& Haghighi, 2014).

These days, ESP courses have become popular and the demand for communicating through ESP is still growing. This has led Iranian universities to include ESP courses in their curriculum as a compulsory course in all the majors. But it seems that learning ESP is limited to learning specific words, basic grammatical points, reading passages and translating them. They mostly disregard learners' personal needs and interests and this decreases motivation in learners' English studies and, in turn, causes poor performance when they intend to use English in their future carriers.

As Jackson (2005) stated, the purpose of undertaking a curriculum evaluation is that it ensures that the learners' needs and requirements are adequately addressed. According to McDonough and Shaw (2003), materials evaluation is required in some situations such as when instructors develop or adopt their materials and when they use other peoples' materials. Some degrees of evaluations are needed in both of these situations. Ansari and Babaei (2002) also noted that teachers or instructors have been responsible for evaluating textbooks so that the evaluation of teaching materials is an influential part of a teacher's task. In ESP, there are three basic kinds of learner assessment: placement tests, achievement tests and proficiency tests. Alderson and Waters (1987, as cited in Hatam \& Shafiei, 2012) considered four main aspects of ESP course evaluation: a) what should be evaluated? b) how can ESP courses be evaluated? c) who should be involved in the evaluation? d) when (and how often) should evaluation take place?

In the Iranian context, the systematic evaluation of textbooks is not usually carried out and students' needs and opinions regarding the materials designed for them are mostly overlooked (Baleghizadeh \& Rahimi, 2011; Salehi, Davari, \& Md Yunus, 2015). The present study concerned evaluation of the above-mentioned textbook in terms of needs and perceptions of Qur'anic Sciences and Tradition students and is an attempt to shed light on the strengths and weaknesses of their ESP course book. Therefore, the following two research questions have been answered in this paper:

1) To what extent has the textbook met the language and learning needs of students of Qur'anic Sciences and Tradition?

2) What are the learners' attitudes towards the textbook?

\section{Literature Review}

Since the early 1960s, ESP has become one of the most prestigious areas of EFL teaching. From that time, lots of studies have been done on ESP although they have not been sufficient. Therefore, a lot of efforts are needed to be done in this area to examine different aspects of ESP.

Course book is an instrument for achieving aims that have been designed based on learners' needs (Zhang, 2007). Jahangard (2007) mentioned that textbook plays an effective role in self-directed learning, material presentation, activities, and they are considered as a reference for learners. According to Ahour and Ahmadi (2012), knowledge and information are conveyed through textbook to the learners in an easy and organized way. According to Bojovic (2006), ESP materials and textbooks should be authentic; they should keep up with what is most recent in the field; and they should be related to the students' specializations.

In fact, evaluation and materials analysis enable instructors to examine inside the materials and to take more control over the way they are designed and how they are used (Littlejohn, 2011). McDonough and Shaw (2003) claimed that evaluation is a beneficial process in its own right due to the fact that it informs teachers about the organizational principles of the materials and helps them to maintain developments in the field. This, in turn, helps teachers to adapt materials realistically.

In the development of an ESP curriculum design for Greek EFL students of computing, Xenodohidis (2002) stated that in addition to needs assessment, the course development process should also include determination of goals and objectives. In order to avoid de-motivation, the goals should be realistic and the objectives should be appropriate to the goals otherwise the students would be de-motivated (Xenodohidis, 2002).

Furthermore, Thein (2006) conducted a study to evaluate the suitability and effectiveness of the textbooks used for teaching English to religious studies students at Myanmar Institute of Technology. Questionnaires, interviews, and classroom observations were used to collect data both from teachers and learners. The study was aimed at investigating the extent to which teachers and learners' expectations match the objectives of the program in developing students' communicative skills and critical thinking. The findings revealed that the textbooks used in the program were not suitable for reasons including 'the textbooks did not contribute to achieve the needs and wants of both teachers and learners', 'they were not effective to promote students' critical thinking', and 'they 
were not effective in improving the students' communicative skills for everyday life situations'. Thein (2006) suggested that textbooks must be localized to meet teachers and learners' needs. He also emphasized the importance of adapting activities that encourage collaborative learning, natural and experiential interactions to help young people think critically.

Jebahi (2009) evaluated different aspects of an ESP textbook, 'Science Vistas', by Dean Curry (1981) regarding the emotional and intellectual reactions and attitudes of the learners towards the contents of the lessons. He used the most common feathers in the three frameworks (Sheldon, 1988; Cunningsworth, 1995; Ur, 1996). By applying questionnaire and interview, he investigated the students' emotions and attitudes.

Zangani (2009) evaluated ESP textbooks used in undergraduate programs at Iranian universities. He investigated whether the textbooks were satisfactory in terms of favorability; whether they incorporated new goals in language learning and teaching; and whether they predicted the language and learning needs of the students.

Al-Tamimi (2010) conducted a survy to investigate the English language needs of petroleum engineering students. The results emphasized the significance of English for petroleum engineering students and identified the students' lacks, wants and necessities regarding the English language skills. His paper concludes with pedagogical implications that may help improve the current English language course based on the students' needs.

Maleki and Kazemi (2012) evaluated and compared 'Medical Terminology' with 'English for the Students of Medicine' according to teachers' and students' attitudes. They employed questionnaires to investigate the extent to which each textbook fulfills the teachers' and students' expectations, and find strong and weak points of the textbooks and make suggestions for their improvement.

Karimi and Sadeghi (2013) evaluated the 'Agricultural Extension and Rural Development ESP Textbook' with analyzing the particular needs of a special group of learners. They discussed the adaptability of the content of these textbooks in agricultural extension and rural development in terms of the learners' needs. They used Hutchinson and Waters' Framework and concluded that learners' needs are the first important things that should be taken into consideration for evaluating an ESP textbook.

\section{Methodology}

\subsection{Participants}

A group of 80 MA Qur'anic Sciences and Tradition students and 6 male and female teachers doing an ESP course formed the sample of this study. The students' age range was 17-40 years. They study at the University of Isfahan, Faculty of Humanities, Qur'anic Sciences and Tradition Department; University of Quranic Sciences and Tradition (Hadith), Isfahan; and the University of Qur'anic Sciences and Tradition in Dolatabad, Isfahan, Iran. All the students had passed their general English course in previous semesters but they had not taken other ESP courses.

\subsection{Instruments}

\subsubsection{Questionnaire}

A questionnaire was used to elicit the participants' perceptions of their ESP textbooks. The questionnaire contained demographic information and the learners' attitudes toward the textbook. All of the items in these sections were designed on a five-point Likert scale of frequency, where $1=$ strongly agree, $2=$ agree $3=$ undecided, $4=$ disagree, and $5=$ strongly disagree. To make the items easy to understand, the researcher translated the questionnaire into Persian using back translation method. The questionnaire was developed by the researcher and two university professors checked its content and face validity. The questionnaire was piloted on 15 ESP students and 2 university teachers. The Cronbach's Alpha Coefficient for students' questionnaire was 0.64 and for teachers' questionnaire was 0.90 .

\subsubsection{Interview}

To determine the students' needs and to achieve the reliability of the findings, an interview was run. It has been mostly adopted from Litz (2005); however, the researcher made some modifications. It was translated using back translation method from English to Persian back to English. Two university professors checked its content and face validity and then it was piloted on 2 students and one teacher.

\subsection{Materials}

The book to be evaluated was "English for the students of Qur'anic Sciences and Tradition" written by Mohsen Jan Nezhad and Jalal-e-Din Jalali. It is a specialized book for MA Qur'anic Sciences and Tradition students to be 
used at the universities in Iran. The book consists of eighteen units. Each unit includes reading passages and different activities such as language practice, comprehension exercises, true and false, multiple choice, comprehension questions and cloze tests. Most parts of the book emphasize the reading skill. No listening exercises have been provided; and this book has not been equipped with charts, figures, tables and color pictures.

\subsection{Procedure}

The study adopted both quantitative and qualitative designs to evaluate the ESP textbook designed for the students of Qur'anic Sciences and Tradition. At first, the researcher talked with the participants about the study for a few minutes and made them aware of the processes they were supposed to go through. They were informed that it was not necessary to write their names, and their answers won't affect their course grade. Then, the questionnaires were distributed among the participants and the required data were collected. Next, in the qualitative part, the book was evaluated through an interview. The participants were asked to give their perceptions of the course book and their needs.

\section{Results and Discussion}

The first research question, "To what extent has the textbook met the language and learning needs of students of Qur'anic Sciences and Tradition?" was answered through interview questions and five questionnaire items. Results indicated that the textbook relatively meets the language and learning the needs of the learners. As Xenodohidis (2002) argued, while the primary issue in designing an ESP course is analysis of learners' specific needs, if needs are clear and easy to understand, learning purposes can be expressed more easily and language for specific courses become more motivating (Jiajing, 2007). The lack of needs analysis is the main reason for unsuitability of many ESP textbooks. In many cases, needs analysis has not been conducted before the course begins so that there is not enough information about the students for whom the textbook is provided. Maybe the materials developers and writers do not have the intended audience in their mind while writing the textbook; therefore, they do not have any predetermined guidelines to follow them for all the courses.

With regard to these five questionnaire items, the analysis of the responses showed that both teachers and students' expectations from this course are to some extent far from what they are dealing with during this course. Learning English as international language, using English to propagate religion, learning adequate specific and practical vocabulary and learning to speak, read and write English articles, as mentioned by most of the students, what they seek to achieve at the end of the course. Although as Celce-Murcia (2001) stated, textbooks are for students and should meet their requirements. The findings implied that the current textbook covers students' needs not as much as they expected. As students believed they were exposed with lots of specific and difficult words which can be beneficial for their academic goals such as M.A. exam but they did not acquire the ability to use them in other goals like communicating. In teachers' points of view, students are expected to use English for getting access to English materials, doing research, and taking part in religious meetings. At the end of the course, their language skills and sub-skills should be improved to some extent that their needs be fulfilled. As they believed, one semester is really a short time for such students that mostly do not have any background knowledge of English and are overload with lots of English materials and it is not practical to fulfill all their requirements.

Regarding the second research question, "What are the learners' attitudes toward the textbook?" ten items in the questionnaires and two questions in the interviews were considered to answer it. The results of the study revealed that $40 \%$ of the participants had a positive attitude toward the ESP textbook and less than $20 \%$ of them did not have positive attitude. The results of the students' interviews revealed that they felt the course book is useful for their future job needs. As Tok (2010) stated, "textbooks play prominent roles in the teaching and learning process and they are the primary agents of conveying the knowledge to the learners". Sheldon (1988) suggested that textbooks do not only represent the visible heart of any ELT program, but also offer considerable advantages for both students and the teachers when they are being used in ESL/EFL classrooms. The participants were pleased with the book although they mentioned some points which should be considered by material developers. To provide an appropriate and suitable textbook for learners, different issues should be taken into consideration like the background knowledge and English level of the learners. However, in most of the students' perceptions, the book was not in harmony with their English proficiency, and English level of the learners was overlooked. In spite of passing a general English course, students still thought that they were dealt with difficulties that could not cope with. Some participants mentioned the problem of supplementary materials. These materials can help students to improve their English and learn the textbook contents even better. But the course suffers from lack of it. ESP textbooks should arouse the interest of the students and be motivating. One of the techniques which can be used to achieve this goal is to use pictures, illustrations, tasks, and authentic 
materials but this book is not accompanied with pictures and illustrations. According to McDonough and Shaw (1993), two important criteria for textbook evaluation are clarity of layout and visuals like tables, charts, and diagrams. The results of the teachers' interviews also showed that they were pleased with the book. They stated that everything is well-arranged and content is good, but students are not proficient.

\section{Conclusion and Suggestions}

Evaluation of the ESP textbook of Qur'anic Sciences and Tradition taught at some Universities of Iran gave clear insights of its learners' attitudes towards the textbook and their needs. As the findings of the study revealed, the general consensus among students was that the ESP textbook relatively met the students' requirements in general sense. Regarding teaching methodology, it should be mentioned that students' perceptions were not in harmony with the teachers' perceptions. The teachers felt they were effective and the method was satisfactory, but the learners preferred changing in teaching methods to be more learner-centered. It seems background knowledge and English level of the learners had been overlooked. The course suffers from lack of supplementary materials which can help students improve their English and learn the textbook contents even better.

In terms of language skills, the results showed the students' satisfaction with the reading skill, reading passages, and associated activities. On the contrary, the textbook insufficiently focused on speaking ability. Unfortunately, nothing had been done for listening skill. More practice is needed for improving the writing skill. The vocabulary load is too much in students' view; of course the textbook contains basic grammatical patterns.

The findings also indicated that the current textbook covers varieties of relevant topics to meet the needs of the Qur'anic Sciences and Tradition students. The book includes exercises such as language practice, comprehension exercises, true and false, multiple choice, comprehension questions and cloze tests. These tasks expand students' knowledge of vocabulary, and improve their reading skill. In addition, it includes a part to answer some questions orally to improve students' speaking ability, but listening exercises have not been provided. Similarly, this book does not contain charts, flowcharts, diagrams, figures, tables and color pictures.

The textbook materials should be equipped with activities like class discussion, prediction activities, skimming and scanning. It should also foster collaborative learning. The book should provide the learners with activities which arouse the learners' interest. Moreover, pronunciation practice should be included in the textbook. The teachers of the book believed that the students are not very knowledgeable in English and their knowledge is confined to limited vocabulary. They believed that the time of the course is too short so that all the ESP students' requirements cannot be fulfilled.

In general, according to the participants' perceptions, the course book is appropriate for the students of the Qur'anic Sciences and Tradition course on the whole. However, some important changes are needed to make the textbook meet the students' needs. Of course, "no single textbook can meet the needs of a large and different group of language learners" (Riasati \& Zare, 2010, p. 60). Therefore, to gain effective learning outcomes, as Riasati and Zare suggested, teacher should apply the appropriate teaching methodologies and techniques to compensate for the shortcomings of a certain textbook.

\section{References}

Ahour, T., \& Ahmadi, E. (2012). Retrospective Evaluation of Textbook "Summit 2B" for Its Suitability for EFL Undergraduate Students. Journal of Educational and Social Research, 2(5), 195-202.

Al-Tamimi, A., \& Shuib, M. (2010). Investigating the English Language Needs of Petroleum Engineering Students at Hadhramout University of Science and Technology. The Asian EFL Journal, 6(1), 6-34.

Ansary, H., \& Babaei, E. (2002). Universal Characteristics of EFL/ESL Textbooks: A Step towards Systematic Textbook Evaluation. The Internet TESL Journal, 8(2). Retrieved February 7, 2010, from http://iteslj.org/Articles/Ansary-Textbooks/

Baleghizadeh, S., \& Rahimi, A. H. (2011). Evaluation of an ESP Textbook for the Students of Sociology. Journal of Language Teaching and Research, 2(5), 1009-1014. http://dx.doi.org/10.4304/jltr.2.5.1009-1014

Bojovic, M. (2006). Teaching Foreign Languages for Specific Purposes: Teacher Development. Paper presented at the 31st Annual Association of Teacher Education in Europe. Retrieved from http://www.pef.uni-lj.si/atee/978-961-6637-06-0/487-493

Celce-Murcia, M. (2001). Teaching English as a Second or Foreign Language (3rd ed.). Boston: Heinle \& Heinle.

Cunningsworth, A. (1995). Choosing Your Coursebook. UK: Heinemann English Language Teaching. 
Danaye Tous, M., \& Haghighi, S. (2014). Evaluation of ESP Textbooks: Evidence from ESP Textbook of Computer Engineering Major, University of Guilan, Iran. International Journal of Research Studies in Language Learning, 2(3), 55-68.

Hatam, A. H., \& Shafiei, Sh. (2012). The Evaluation of the Effectiveness of ESP Courses in Enhancing Technical Translation Proficiency: A Case Study of ESP Course for Mechanical Engineering Students. English Language Teaching, 5(5), 68-78.

Hutchinson, T., \& Waters, A. (1993). English for Specific Purposes: A Learning-Centered Approach. Cambridge: Cambridge University Press.

Jackson, J. (2005). An Inter-university, Cross-disciplinary Analysis of Business Education: Perceptions of Business Faculty in Hong Kong. English for Specific Purposes, 24(3), 293-306.

Jahangard, A. (2007). The Evaluation of the EFL Materials Taught at Iranian Public High Schools. Asian EFL Journal, 9, 130-150.

Jan-Nezhad, M., \& Jalali, J. (2012). English for the Students of Qur'anic Sciences and Tradition. Samt Publications, Tehran, Iran.

Jebahi, K. (2009). Using a Commercially Developed ESP Textbook: A Classroom Dilemma. The Asian EFL Journal, 5(2), 75-92.

Jiajing, G. (2007). Designing an ESP course for Chinese university students of business. The Asian EFL Journal, 3(1). Retrieved October 19, 2008, from http://www.asian-efl-journal.com

Karimi, L., \& Sadeghi, B. (2013). Agricultural Extension and Rural Development ESP Textbook Evaluation in Bu Ali Sina University, Iran. Journal of English Linguistics Research, 2(1), 113-127.

Karimi, S. (2006). ESP Textbook Evaluation: English for the Students of Computer (Unpublished Master's Thesis). AllamehTabataba'i University, Tehran, Iran.

Littlejohn, A. (2011). The Analysis of Language Teaching Materials: Inside the Trojan Horse. In B. Tomlinson (Ed.), Materials Development in Language Teaching (pp. 179-211). Cambridge: Cambridge University Press.

Litz, D. R. A. (2005). Textbook Evaluation and ELT Management: A South Korean Case Study. Asian EFL Journals. Retrieved from http://www.asian-efljournal.com/Litz_thesis.pdf

Maleki, A., \& Kazemi, M. (2012). The Evaluation and Comparison of Two Most Widely Used Textbooks for Teaching English to the Iranian Students of Medicine, Zanjan Medical Sciences University, Zanjan, Iran, Iranian EFL Journal. The Iranian EFL Journal, 8(3).

McDonough, J., \& Shaw, C. (1993). Materials and Methods in ELT. Oxford: Blackwell.

McDonough, J., \& Shaw, C. (2003). Materials and Methods in ELT: A Teacher's guide (2nd ed.). Oxford: Blackwell Publishing.

Riasati, M. J., \& Zare, P. (2010). EFL Teachers' Perspectives on "New Interchange". Studies in Literature and Language, 1(8), 54-60.

Riazi, A. M. (2003). What Textbook Evaluation Schemes tell us? A Study of the Textbook Evaluation Schemes of Three Decades. In W. A. Renandya (Ed.), Methodology and Materials Design in Language Teaching (pp. 52-68). Singapore: SEAMEO Regional Center.

Richards, J. C., \& Rodgers, T. (2001). Approaches and Methods in Language Teaching (2nd ed.). Cambridge University Press.

Robinson, P. (1991). ESP Today: A Practitioner's Guide. New York: Prentice Hall.

Salehi, H., Davari, A., \& Md Yunus, M. (2015). Evaluation of an ESP Course of Qur'anic Sciences and Tradition. International Education Studies, 8(1), 29-37.

Sheldon, L. E. (1988). Evaluating ELT Textbooks and Materials. ELT Journal, 42, 237-246. http://dx.doi.org/10.1093/elt/42.4.237

Thein, N. (2006). Evaluating the Suitability and Effectiveness of Three English Course Books at Myanmar Institute of Technology (Unpublished MA Thesis). University of Thailand. Thailand.

Tok, H. (2010). TEFL Textbook Evaluation: From Teachers' Perspectives. Retrieved from http://www.academicjournals.org/ 
Ur, P. (1996). A Course in Language Teaching: Practice and Theory. Cambridge: Cambridge University Press.

Xenodohidis, T. H. (2002). An ESP Curriculum for Greek EFL Students of Computing: A New Approach. ESP World, 1(2). Retrieved November 11, 2005, from http://esp-world.7p.com/Articles

Zangani, E. (2009). The ESP Textbook Problem: The Evaluation of ESP Textbooks in Humanities in the Undergraduate Program of Iranian Universities, Zanjan Islamic Azad University. The Asian ESP Journal, 2(5), 93-106.

Zhang, Y. (2007). Literature Review of Material Evaluation. Sino-US English Teaching, 4(6), 28-31.

\section{Copyrights}

Copyright for this article is retained by the author(s), with first publication rights granted to the journal.

This is an open-access article distributed under the terms and conditions of the Creative Commons Attribution license (http://creativecommons.org/licenses/by/3.0/). 